\title{
Correction to: CD103-positive CSC exosome promotes EMT of clear cell renal cell carcinoma: role of remote MiR-19b-3p
}

Lu Wang ${ }^{1 \dagger}$, Guang Yang ${ }^{2+}$, Danfeng Zhao ${ }^{1}$, Jiaqi Wang ${ }^{1}$, Yang Bai ${ }^{1}$, Qiang Peng ${ }^{1}$, Hongzhi Wang ${ }^{1}$, Ruizhe Fang ${ }^{1}$,

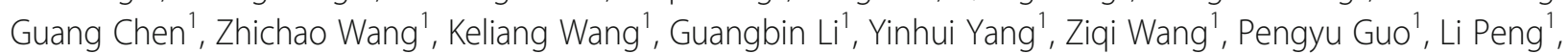
Dayong $\mathrm{Hou}^{1}$ and Wanhai $\mathrm{Xu}^{1 *}$

Correction to: Mol Cancer 18, 86 (2019) https://doi.org/10.1186/s12943-019-0997-z

After the publication of this work [1], the authors reported errors in Fig. $4 \mathrm{a}$ and $\mathrm{b}$. The image of "ACHN cells/ NC-48h" in Fig. 4a was unintentionally covered during figure processing, so the image of "ACHN cells/ C-Exo 48h" in Fig. 2b was showed duplicately. In Fig. 4b, the images of "786-O cells" were accidentally deleted, but the images of "ACHN cells" were duplicative displayed. The errors do not change the original conclusions of the article. The authors apologize for any inconvenience that the inaccuracy may have caused.
The original article can be found online at https://doi.org/10.1186/s12943019-0997-z.

* Correspondence: xuwanhai@hrbmu.edu.cn

${ }^{+}$Lu Wang and Guang Yang contributed equally to this work.

'Department of Urology (Heilongjiang Key Laboratory of Scientific Research in Urology), the Fourth Hospital of Harbin Medical University, No. 37 Yi-Yuan Street, Nangang District, Harbin, Heilongjiang Province 150081, People's Republic of China

Full list of author information is available at the end of the article
A

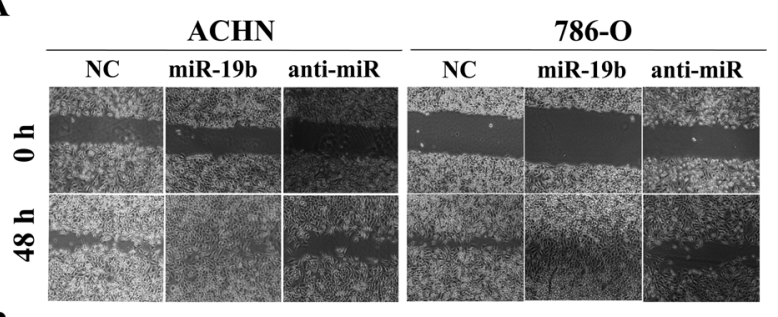

B

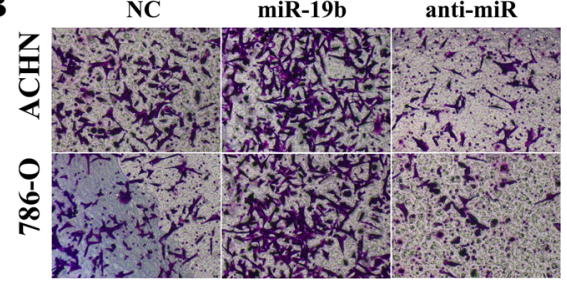

Author details

'Department of Urology (Heilongjiang Key Laboratory of Scientific Research in Urology), the Fourth Hospital of Harbin Medical University, No. 37 Yi-Yuan Street, Nangang District, Harbin, Heilongjiang Province 150081, People's Republic of China. ${ }^{2}$ Department of Neurosurgery, The First Affiliated Hospital of Harbin Medical University, Harbin, Heilongjiang Province, People's Republic of China.

Published online: 24 September 2020

Reference

1. Wang L, Yang G, Zhao D, et al. CD103-positive CSC exosome promotes EMT of clear cell renal cell carcinoma: role of remote MiR-19b-3p. Mol Cancer. 2019;18:86 https://doi.org/10.1186/s12943-019-0997-z.

(c) The Author(s). 2020 Open Access This article is licensed under a Creative Commons Attribution 4.0 International License, which permits use, sharing, adaptation, distribution and reproduction in any medium or format, as long as you give appropriate credit to the original author(s) and the source, provide a link to the Creative Commons licence, and indicate if changes were made. The images or other third party material in this article are included in the article's Creative Commons licence, unless indicated otherwise in a credit line to the material. If material is not included in the article's Creative Commons licence and your intended use is not permitted by statutory regulation or exceeds the permitted use, you will need to obtain permission directly from the copyright holder. To view a copy of this licence, visit http://creativecommons.org/licenses/by/4.0/ The Creative Commons Public Domain Dedication waiver (http://creativecommons.org/publicdomain/zero/1.0/) applies to the data made available in this article, unless otherwise stated in a credit line to the data. 